\title{
Pull factors influencing tourist perception in rural tourism: The case study of Ca Mau province, Viet Nam
}

\author{
Ngo Thi Ngoc Tram
}

\begin{abstract}
This quantitative study identifie factors affecting tourist perception in the context of rural tourism in Ca Mau province - the southernmost province of Vietnam, belonging to the Mekong Delta. In which, local culture, infrastructure and marketing communication has positive relation with tourist perception, while services \& entertainment has negative relation. The research produced 400 structured questionnaires to collect data on these factors in Ca Mau, and found that there is a significant influence on tourist perception in rural tourism sector, which $58 \%$ changing in tourist perception is explained by the independent variables. The regression equation is set as:

$\mathrm{Y}=1.423+0.343 \mathrm{X} 1-0.082 \mathrm{X} 2+0.273 \mathrm{X} 3+$ $0.189 X 4$

(Y= Tourist Perception; X1= Local Culture; X2= Services \& Entertainment;

X3 = Infrastructure; $\quad$ X4 $=\quad$ Marketing communication)
\end{abstract}

Keywords - rural tourism, pull factors, tourist perception

\section{INTRODUCTION}

\begin{abstract}
A $s$ the southernmost province of Viet Nam with the national landmark named $\mathrm{Ca} \mathrm{Mau}$ cape, $\mathrm{Ca} \mathrm{Mau}$ province is an attractive geographical tourism destination to domestic as well as foreign visitors. It also has the chance in creating specific tourism products and brand positioning of its own with two interlaced ecosystems of mangrove and brackish water forest. However, the rural areas are still underdeveloped with a considerable rate of poor households. It can be shown from the figure 1 that the percentage of poor households in rural areas of Viet Nam is nearly tripled than in the urban areas $(9.2 \%$ and $2.5 \%$ respectively).
\end{abstract}

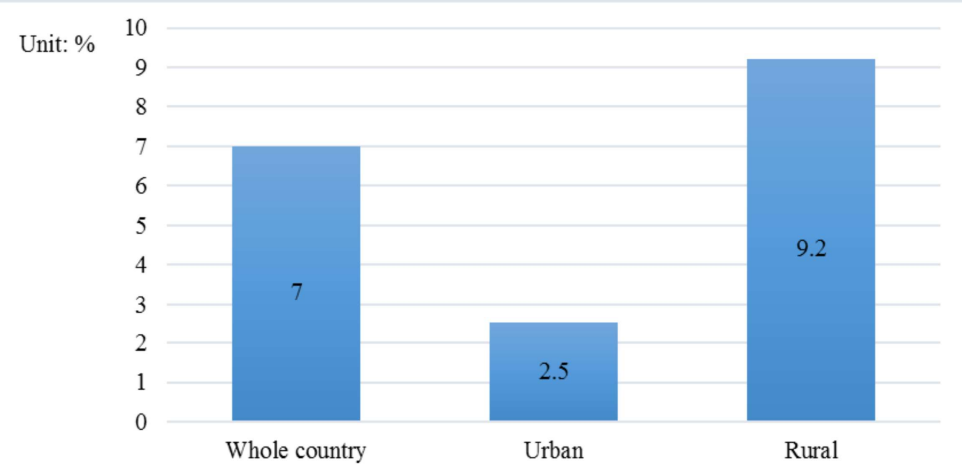

Figure 1. Percentage poor households divided by area of Viet Nam by the end of 2015

(Viet Nam General Statistics Office, 2015) 
Meanwhile, the number of tourists visiting Viet Nam

2015 as demonstrating in the figure 2 . has an increasing trend through the period of $2010-$

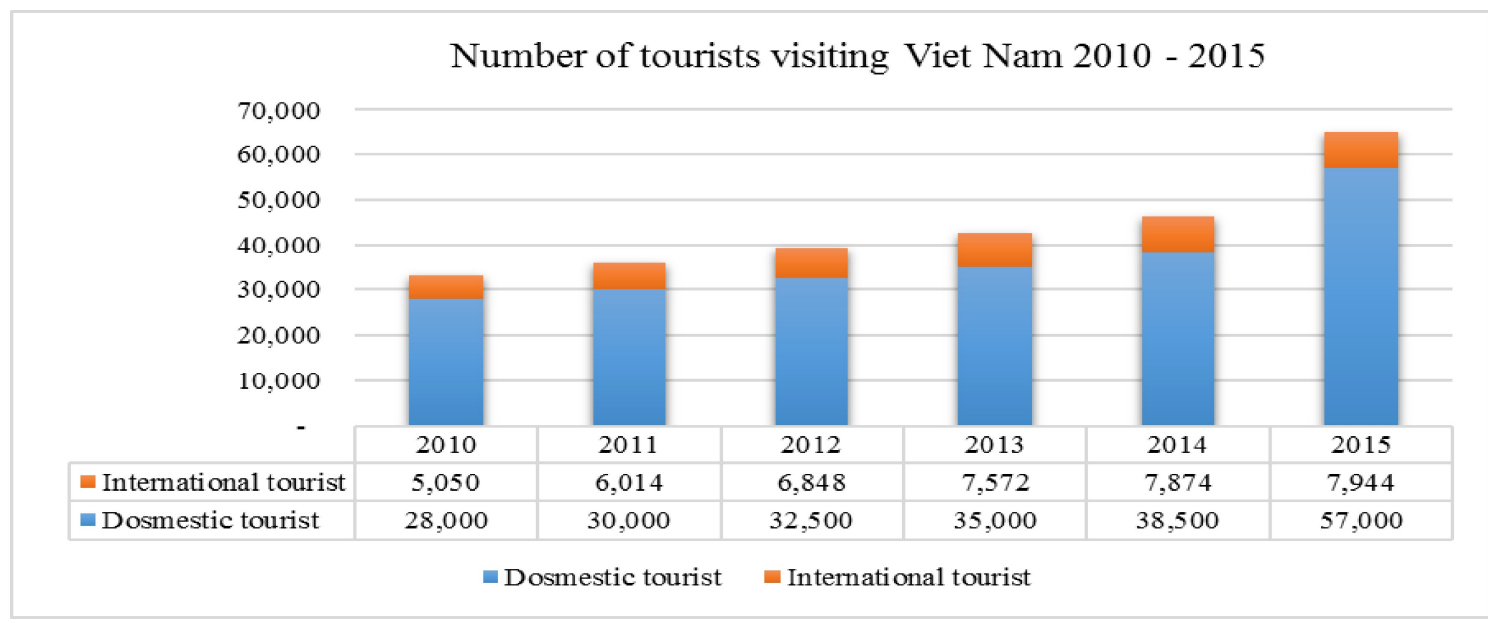

Figure 2. Number of tourist visiting Viet Nam 2010 - 2015 [51]

Even though tourism is growing as fast as a flourishing industry with tremendous advances contributing by e-tourism, rural tourism is still under developed compared to urban tourism. "Developing rural tourism has its challenges. Any successful tourism development depends on commercial, economic, and logistical issues, such as the quality of the product, accessibility and infrastructure of the destination, availability of skills, marketing communication and interest of investors. Thus, ways to deal with these challenges are needed [39].

\section{LITERATURE REVIEW}

Rural tourism focuses on recreation in rural setting, to participate or experimentation activities, events and attractions that tourists are not allowed in urban areas. Thus, rural tourism is becoming increasingly attractive as tourists become more mobile and seek a change from city life, so that it should be widely discovered tourist perception through pull factors. The pull factors influencing tourist perception is one major importance. It cannot be said about rural tourism if there are not preserved popular traditions and customs.

In the context of tourism research, there are many authors concerning about the factors influencing on the way tourists perceive a destination image. However, there are limited of researches related to rural tourism as a specific aspect. In order to define the factors which have impacts on tourist perception in the context of rural tourism, the research gathers from plenty of sources and develop the pull factor definition along with their indicators. The table 1 shows all the researchers whose findings support the concept of this study.

Table 1

The supporting authors related to the research

\begin{tabular}{|l|l|l|}
\hline \multicolumn{1}{|c|}{ Factors } & \multicolumn{1}{|c|}{ Indicators } & \multicolumn{1}{c|}{ Authors } \\
\hline $\begin{array}{l}\text { Tourism } \\
\text { infrastructure }\end{array}$ & $\begin{array}{l}\text { - Accommodation } \\
\text { - Transportation at the destination }\end{array}$ & {$[13,17,30,53,24,28,44,38,40,49]$} \\
\hline Services \& & $\begin{array}{l}\text { - Equipment rental } \\
\text { Entertainment }\end{array}$ & $\begin{array}{l}\text { leisure } \\
\text { - Retail network }\end{array}$ \\
& - Information system & {$[27,26,5,44,3,40,6,9,18]$} \\
\hline
\end{tabular}




\begin{tabular}{|c|c|c|}
\hline Factors & Indicators & Authors \\
\hline Local culture & $\begin{array}{l}\text { - } \text { Traditions } \\
\text { - Gastronomy } \\
\text { - } \quad \text { Music and art (such as paintings, } \\
\text { concerts \& sculptures) } \\
\text { - History of the region, including } \\
\text { its visual reminders } \\
\text { - Types of work engaged in by } \\
\text { residents and technology they use }\end{array}$ & {$[50,43,45,33,25,42,47,10,16,15,29]$} \\
\hline $\begin{array}{l}\text { Arketing } \\
\text { communication }\end{array}$ & $\begin{array}{l}\text { - Television } \\
\text { - Internet } \\
\text { - Print media } \\
\text { - Friends and Relatives } \\
\text { - Festivals and Events }\end{array}$ & {$[37,41,23,2,14,35,31]$} \\
\hline
\end{tabular}

The future trends in the rural tourism industry include more green and eco-loggings: development of tourist and agro-tourist boarding houses, more personalized boutiques, intelligent tourist boarding houses with advanced technology, more emphasis on the rural activities, more pedestrian journeys. The research is an exploratory study seeing that literature review has not revealed many projects in the scope of $\mathrm{Ca}$ Mau province which led to formulate the following research hypotheses as mentioned below.
H1: Tourism infrastructure positively influences on tourist perception

$\mathrm{H} 2$ : Services \& entertainment positively influences on tourist perception

H3: Local culture positively influences on tourist perception

H4: Marketing communication positively influences on tourist perception

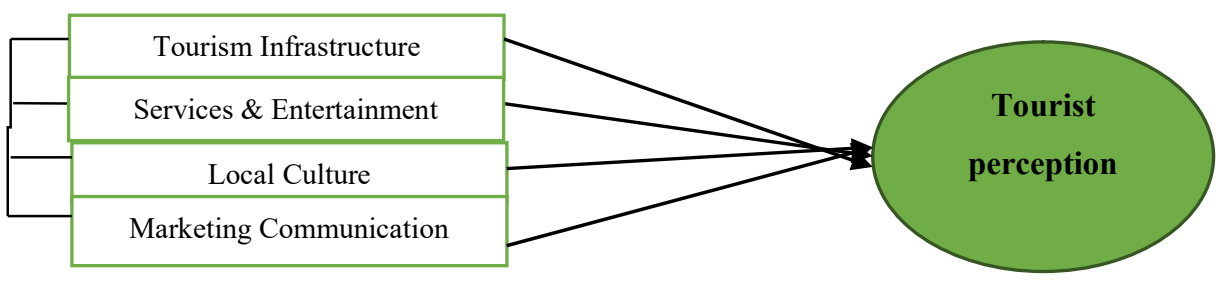

Figure 2. Pull factors impact on tourist perception in rural tourism framework

\section{METHODOLOGY}

\subsection{Research design}

This research was designed using a quantitative research method. A descriptive research using a cross-sectional study based on a questionnaire survey, or survey research, was conducted for this study. The survey research was employed for this study in order to describe how these pull factors which are infrastructure, services \& entertainment, local culture, and marketing communication influencing tourist perception in $\mathrm{Ca}$ Mau province. This study included independent variables as mention before and one dependent variable as tourist perception.

\subsection{Population}

Since the objective of this research is to study the factors affecting tourist's perception. Rural tourism at the tourist aspect, the unit of analysis is, therefore, the tourists. The study population refers to the large groups of people including the international and domestic tourists visiting $\mathrm{Ca}$ Mau province. The total number of tourist visiting Ca Mau province in 2015 was 986,550 that comprised of 21,050 international tourists and 965,500 domestic tourists, with the proportion of $2 \%$ and $98 \%$ respectively [8]. 


\subsection{Sample size and sampling technique}

Sampling is used to select the respondents. A sample should contain a complete listing of every element in the target population, and every element should be included only once. According to Yamane (1967), the number of sample size should be followed the formula as below:

$$
n=\frac{N}{1+N(e)^{2}}
$$

In which: $\mathrm{n}=$ sample size

$$
\begin{aligned}
& \mathrm{N}=\text { population size } \\
& \mathrm{e}=\text { the level of precision which is } \\
& \text { expected as } 0.05
\end{aligned}
$$

When this formula is applied to the above sample, the number of sample size is as below:

$$
n=\frac{986,550}{1+986,550(0.05)^{2}}=399.84 \text { (aprrox.) }
$$

From the result of calculating sample size based on Yamane formula, this study applies the number of 400 respondents which is nearly equal to 399.84 as illustrating above.

The research applies non - probability sampling method to select the respondents, based on the specified characteristics of population of interest and then locate individuals who match the needed characteristics. Simple random sampling was employed by using three simple steps to assure that different units in population have equal probabilities of being chosen, which are discussed below:

- Five travel agents which offer Ca Mau province as a destination for their program tour are intentionally selected.

- 80 tourists (respondents) will be asked to respond the survey from each selected travel agent.

- 400 respondents will be chosen rely on two criteria: 1. stay at least one night in $\mathrm{Ca}$ Mau province; and 2. tourists include 93\% domestic and 7\% international ones.

\subsection{Data collection process}

Step 1: Finding the literatures on rural tourism, pull factors and tourist perception

Step 2: Organizing the literature reviews and proposing the conceptual framework
Step 3: Developing the questionnaire in both English and Vietnamese language based on the previous theories and the questionnaire format of Kipchillat (2004) [21]

Step 4: Checking Validity (IOC) and Reliability (Cronbach's Alpha)

a. Validity (IOC): Questionnaires were evaluated by three experts specializing in rural tourism and research statistics.

b. Reliability (Pilot test): 30 questionnaires were distributed to tourists who were visiting or used to visit $\mathrm{Ca}$ Mau province, Viet Nam.

Step 5: Distributing 480 questionnaires by email and face to face with the international and domestic tourists in the cooperation of co-workers as local people and local staffs who well understand about the selected places.

Step 6: Using SPSS version 22.0 in order to analyzing the data:

a.Descriptive Statistics as frequency, percentage, mean, and cross-tabulation for measuring the demographic profile of respondents.

b. Exploratory Factor Analysis was employed to classify the pull factors influencing tourist perception in rural tourism

c.Multiple Regression Analysis was employed to examine the relationship between pull factors and tourist perception in rural tourism concept.

Step 7: Writing the research findings, conclusion, discussion and recommendations for the future research

Data for this research is collected through questionnaires in both English and Vietnamese language. Due to the selected sample size of 400 people, therefore 480 questionnaires was distributed from both international and domestic tourists visiting $\mathrm{Ca}$ Mau province. Prior the field survey is taken place, researcher conducted pilot study to detect error of the questionnaire. The research was conducted under cooperation with co-workers as local people and local staffs who well understand about the selected places. 


\section{RESULTS}

\subsection{Description of respondents}

Table 2

Profile of respondents by frequencies

\begin{tabular}{|c|l|c|c|}
\hline & $\mathrm{n}=400$ & Frequency & Percent \\
\hline \multirow{4}{*}{ Gender } & Male & 155 & 38.8 \\
\cline { 2 - 4 } & Female & 245 & 61.3 \\
\hline \multirow{4}{*}{ Marital status } & Married & 99 & 24.8 \\
\cline { 2 - 4 } & Unmarried & 301 & 75.3 \\
\hline \multirow{5}{*}{ Education } & $20-30$ & 298 & 74.6 \\
\cline { 2 - 4 } & $31-40$ & 41 & 10.3 \\
\cline { 2 - 4 } & $41-50$ & 24 & 6.0 \\
\cline { 2 - 4 } & $51-60$ & 29 & 2.3 \\
\cline { 2 - 4 } & $>60$ & 8 & 1.8 \\
\hline & Secondary school degree & 7 & 12.3 \\
\cline { 2 - 4 } & High school degree & 49 & 78.3 \\
\cline { 2 - 4 } & College/ bachelor degree & 313 & 7.8 \\
\cline { 2 - 4 } & Higher than bachelor degree & 31 & \\
\hline
\end{tabular}

Table 3

Profile of respondents cross-tabulations

\begin{tabular}{|c|c|c|c|c|c|c|c|c|}
\hline & \multicolumn{8}{|c|}{ Occupation } \\
\hline & 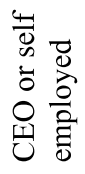 & 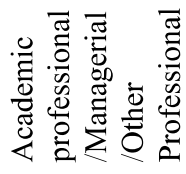 & 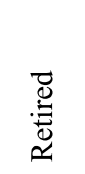 & $\frac{\overrightarrow{\widetilde{U}}}{\frac{\vec{U}}{0}}$ & 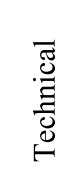 & $\begin{array}{l}\stackrel{\vec{E}}{\tilde{E}} \\
\text { 总 }\end{array}$ & $\frac{\bar{\Phi}}{\stackrel{ \pm}{0}}$ & $\begin{array}{l}\vec{\pi} \\
\stackrel{0}{0}\end{array}$ \\
\hline Male & $9.7 \%$ & $8.4 \%$ & $0.0 \%$ & $18.7 \%$ & $7.1 \%$ & $45.8 \%$ & $10.3 \%$ & $100 \%$ \\
\hline Female & $6.9 \%$ & $7.8 \%$ & $3.3 \%$ & $17.1 \%$ & $6.1 \%$ & $45.7 \%$ & $13.1 \%$ & $100 \%$ \\
\hline Total (\% within gender) & $8.0 \%$ & $8.0 \%$ & $2.0 \%$ & $17.8 \%$ & $6.5 \%$ & $45.8 \%$ & $12.0 \%$ & $100 \%$ \\
\hline
\end{tabular}

\begin{tabular}{|l|l|r|r|r|r|}
\hline \multicolumn{2}{|c|}{} & Nationality & Vietnamese & Non-Vietnamese & Total \\
\hline \multirow{2}{*}{ Gender } & Male & & $89.7 \%$ & $10.3 \%$ & $100 \%$ \\
\cline { 2 - 6 } & Female & & $95.5 \%$ & $4.5 \%$ & $100 \%$ \\
\hline \multicolumn{2}{|l|}{ Total (\% within gender) } & & $93.2 \%$ & $6.8 \%$ & $100 \%$ \\
\hline
\end{tabular}


Table 4

Cronbach's Alpha accreditation for created components

\begin{tabular}{|c|c|c|c|c|c|c|c|}
\hline Rotated Component Matrix & & & & & 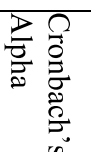 & 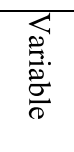 & 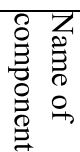 \\
\hline Component & 1 & 2 & 3 & 4 & & & \\
\hline To understand the resident lifestyle & 0.803 & & & & \multirow{5}{*}{0.819} & \multirow{5}{*}{$\begin{array}{l}\text { c11 } \\
\text { c10 } \\
\text { c7 } \\
\text { c9 } \\
\mathrm{m} 12\end{array}$} & \multirow{5}{*}{ 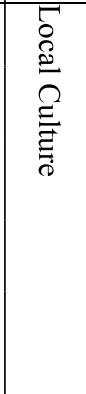 } \\
\hline $\begin{array}{l}\text { To visit historical attractions and understand about } \\
\text { the history of the region }\end{array}$ & 0.765 & & & & & & \\
\hline To increase knowledge about different tradition & 0.749 & & & & & & \\
\hline $\begin{array}{l}\text { To enjoy the local music and art (such as paintings, } \\
\text { concerts \& sculptures) }\end{array}$ & 0.729 & & & & & & \\
\hline $\begin{array}{l}\text { Television (learning local culture through } \\
\text { documentary movies mostly through television } \\
\text { channel) }\end{array}$ & 0.661 & & & & & & \\
\hline $\begin{array}{l}\text { Equipment rental companies are available for } \\
\text { tourists }\end{array}$ & & 0.864 & & & \multirow{4}{*}{0.822} & \multirow{4}{*}{$\begin{array}{l}\text { i6 } \\
\text { i3 } \\
\text { i4 } \\
\text { i5 }\end{array}$} & \multirow{4}{*}{ 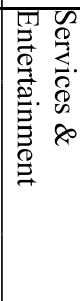 } \\
\hline $\begin{array}{l}\text { Service in the range of active leisure in } \mathrm{Ca} \mathrm{Mau} \\
\text { province is attractive }\end{array}$ & & 0.830 & & & & & \\
\hline $\begin{array}{l}\text { Retail network at the destination is sufficient for the } \\
\text { trip }\end{array}$ & & 0.749 & & & & & \\
\hline $\begin{array}{l}\text { Information system is convenient for connecting, } \\
\text { communicating }\end{array}$ & & 0.660 & & & & & \\
\hline $\begin{array}{l}\text { Ca Mau province has a suitable type of } \\
\text { accommodation }\end{array}$ & & & 0.817 & & \multirow{2}{*}{0.636} & \multirow{2}{*}{$\begin{array}{l}\text { i1 } \\
\text { i2 }\end{array}$} & \multirow{2}{*}{ 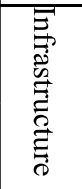 } \\
\hline $\begin{array}{l}\text { Transportation at the destination has been } \\
\text { improving }\end{array}$ & & & 0.772 & & & & \\
\hline Friends and Relatives & & & & 0.898 & \multirow{2}{*}{0.725} & \multirow{2}{*}{$\begin{array}{l}\mathrm{m} 16 \\
\mathrm{~m} 17\end{array}$} & \multirow{2}{*}{ 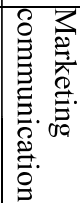 } \\
\hline Festivals and Events & & & & 0.746 & & & \\
\hline
\end{tabular}

Table 5

Bivariate correlations of the variables

\begin{tabular}{|c|c|c|c|c|c|c|}
\hline $\begin{array}{l}\text { Pearson's } \\
\text { Correlation }\end{array}$ & $\mathrm{Y}$ & $\mathrm{X} 1$ & $\mathrm{X} 2$ & $\mathrm{X} 3$ & $\mathrm{X} 4$ & \multirow{6}{*}{$\begin{array}{l}* * \mathrm{P}<.01 \\
\mathrm{X} 1=\text { Local Culture; } \\
\mathrm{X} 2=\text { Services \& Entertainment; } \\
\mathrm{X} 3=\text { Infrastructure; } \\
\mathrm{X} 4 \text { = Marketing communication; } \\
\mathrm{Y}=\text { Tourist perception }\end{array}$} \\
\hline $\mathrm{Y}$ & 1 & & & & & \\
\hline $\mathrm{X} 1$ & $0.648 * *$ & 1 & & & & \\
\hline $\mathrm{X} 2$ & $0.205^{* *}$ & $0.237 * *$ & 1 & & & \\
\hline $\mathrm{X} 3$ & $0.481 * *$ & $0.310^{* *}$ & $0.476^{* *}$ & 1 & & \\
\hline $\mathrm{X} 4$ & $0.551 * *$ & $0.484 * *$ & $0.163^{* *}$ & $0.179 * *$ & 1 & \\
\hline
\end{tabular}


Table 6

Regression Coefficients of important variables

\begin{tabular}{|c|c|c|c|c|c|c|}
\hline Full factors & \multicolumn{2}{|c|}{ Unstandardized Coefficients } & $\mid \begin{array}{l}\text { Standardized } \\
\text { Coefficients }\end{array}$ & $\mathrm{t}$ & Sig. & \multirow{7}{*}{$\begin{array}{l}\text { R2 Square }=0.580 ; \\
\text { F }=138.747 \\
\text { p-value }=0.000 \\
\text { X1 = Local Culture; } \\
\text { X2 = Services \& Entertainment; } \\
\text { X3 = Infrastructure; } \\
\text { X4 = Marketing communication }\end{array}$} \\
\hline & $\mathrm{B}$ & Std. Error & Beta & & & \\
\hline \multirow{5}{*}{$\begin{array}{l}\text { Constant } \\
\text { X1 } \\
\text { X2 } \\
\text { X3 } \\
\text { X4 }\end{array}$} & 1.423 & 0.131 & & 10.879 & 0.000 & \\
\hline & 0.343 & 0.032 & 0.418 & 10.874 & 0.000 & \\
\hline & -0.082 & 0.028 & -0.110 & -2.952 & 0.003 & \\
\hline & 0.273 & 0.030 & 0.349 & 9.194 & 0.000 & \\
\hline & 0.189 & 0.023 & 0.304 & 8.200 & 0.000 & \\
\hline
\end{tabular}

Table 7

Frequency of hearsay of $\mathrm{Ca}$ Mau province

\begin{tabular}{|l|c|c|}
\hline Hearsay of Ca Mau province & Frequency & Percent \\
\hline Trade Fairs \& Exhibition & 21 & $3.3 \%$ \\
\hline Friends and relatives & 232 & $36.1 \%$ \\
\hline Tour operators/ travel agents & 89 & $13.8 \%$ \\
\hline Media (TV/Magazines/Newspaper, ...) & 103 & $16.0 \%$ \\
\hline Internet & 173 & $26.9 \%$ \\
\hline Other & 25 & $3.9 \%$ \\
\hline Total & 643 & $100.0 \%$ \\
\hline
\end{tabular}

Table 8

Frequency of Times Traveled to Ca Mau province

\begin{tabular}{|l|c|c|}
\hline \multicolumn{1}{|c|}{ Times traveled to Ca Mau } & Frequency & Percent \\
\hline First time & 237 & 27.5 \\
\hline 2 times & 110 & 12.0 \\
\hline 3 - 5 times & 48 & 1.3 \\
\hline More than 5 times & 5 & 100.0 \\
\hline Total & 400 & $78.3 \%$ while higher than \\
\hline
\end{tabular}

\section{DISCUSSION}

Table 2 show that most of respondents are from the age of $20-30$ which accounted for $74.6 \%$, while it was nearly a quarter of number of tourists from the age of $31-40,41-50,51-60$ and $>60$ years old taking account of $10.3 \%, 6 \%, 7.3 \%$ and $2 \%$ in turn. The majority of the tourists visiting $\mathrm{Ca}$ Mau province were university graduated with bachelor degree and above in which bachelor degree tourists was $78.3 \%$ while higher than bachelor degree ones took account for $7.8 \%$. In addition, the number of tourists who had high school and secondary school degree is minor with $12.3 \%$ and $1.8 \%$ in turn.

In term of gender showing in table 3 , there was 9.7\% male CEO or self-employed, $8.4 \%$ male whose job relate to education, $7.1 \%$ male working on technical field, $0 \%$ male who were retired, $18.7 \%$ male officer staffs, $45.8 \%$ male students, 
and $10.3 \%$ male working in other fields. Meanwhile, there were $6.9 \%$ female CEO or selfemployed, $7.8 \%$ female whose job relate to education, $6.1 \%$ female working on technical field, $3.3 \%$ female who were retired, $17.1 \%$ female officer staffs, $45.7 \%$ female students, and $13.1 \%$ female working in other fields. Besides, the percentage of Vietnamese male tourists was less than female ones with $89.7 \%$ and $95.5 \%$ respectively while that kind of number for male foreign tourists was more than the one for female with $10.3 \%$ compared to $4.5 \%$ in turn.

The research found that within the concept of rural tourism with the specific case study of $\mathrm{Ca}$ Mau province, local culture factor takes the most important part to generate and remain the image of rural tourism in tourist perception. Meanwhile, the concept of rural tourism embraces a huge range of activities along with natural and manmade attraction [22]. Consequently, it is necessary to be aware of that infrastructure, marketing communication and services \& entertainment are the supporting and affecting aspects to the way that tourists notice rural tourism with their senses. The statistical relations between variables in regression equation are semipartial (part) correlations. In this study, many aspects of semi-partial correlation can be dealt with using multiple regression. The t-test of the related regression weight (B) provides a significance test for this semi-partial correlation.

Murphy's conceptual framework cited in [21] suggested that perception is one of the factors contributing to tourist demand and it leads to tourist's behaviors. Generally, the results

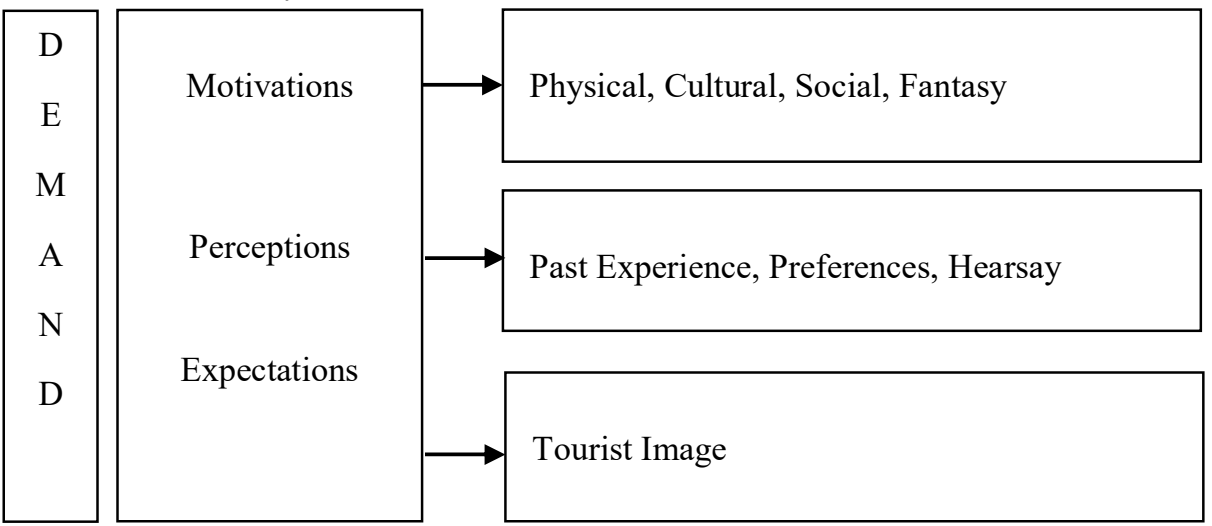

Figure 3. Demand Factors in Murphy's Conceptual Framework (Murphy, Pritchard, \& Smith, 2000)

Figure 3 illustrates that perceptions is one of the factors contributing to tourist demand and it of this study showed the trend of perceiving rural tourism in $\mathrm{Ca}$ Mau province through the descriptive of preferences, past experiences and hearsay. The research findings proposed that tourist preferences in rural destination were defined and revised to be suitable for the case study, which was based on the previous theories and questionnaire format of [21] as the following items: offering unique cuisine; possessing a rich tradition and culture; connecting with local residents to explore the culture; enabling to search information before the trip; offering sufficient information for tourists; being recommended by friends and relatives; offering sufficient retail network.

Perception is the process through which an individual start to select, organize, and interpret information inputs in order to create a meaningful picture of the world (Kotler, Armstrong, \& Cunningham, 2005). Tourists rely on their perception towards the place to make a decision, which should be their holiday destination. If the perception is generated enough through reinforcing by knowledge and experience, it becomes a belief. In the context of understanding tourist behavior, perception is one of demand's components which plays an important role in forming demand due to the bases of choosing any given destination. According to tourism demand factors in Murphy's model, it is identified three crucial elements for perceptions which are past experiences, preference and hearsay. 
order to comprehend tourist behaviors so that it was aroused the demand of a specific destination. Part $\mathrm{C}$ of the questionnaire focuses on tourist perception which comprise of three small parts for measuring the perception. It is included seven statements for measuring tourist preferences, 1 question for evaluating past experiences, and one question for estimating hearsay which are three important items contributing to tourist perception.

This study did not focus on comparing tourist perception between male and female, higher and lower education, different types of occupation, international and domestic tourists. It can be an ideal suggestion for further research to analysis in detail about social - economic characteristics of respondents to understand and classify tourists.

Rural tourism in Ca Mau province should be focused on these three main activities:

Cultural tourism activities for visitors who are interested in local culture, which also embraces the establishment and development of $\mathrm{Ca} \mathrm{Mau}$ province. Culture is the uniqueness that can be recognized for this destination.

Ecotourism activities for visitors who concerntrate on conserving the environment.
Tourists prefer to participate in social activities and preserve cultural values. It is not only a simple traveling method, but it is also contribute to enhance the awareness about the environment as well as a durable rural tourism.

Community tourism activities for visitors who prefer to share daily life with local resident. This can be a specific activity of rural tourism in $\mathrm{Ca}$ Mau province. Not only the tourists can learn and enjoy life together with local resident, but local resident also can receive benefits from this type of rural tourism.

Landscape was not considered as a unique pull factor affecting tourist perception in the context of rural tourism in $\mathrm{Ca}$ Mau province. In geographical aspect, Ca Mau belongs to Mekong delta along with another twelve provinces and city. Therefore, it shares the natural benefits with the other destinations. Besides, while the other provinces and city of Mekong delta have been pushing and leading investment in rural tourism to bring out especially natural landscape, $\mathrm{Ca}$ Mau should be creative in the way to promote rural tourism towards to tourist perception. In another words, it is not a highlighting factor of $\mathrm{Ca} \mathrm{Mau}$ province when mentioning to landscape.

\subsection{Theoretical implication}

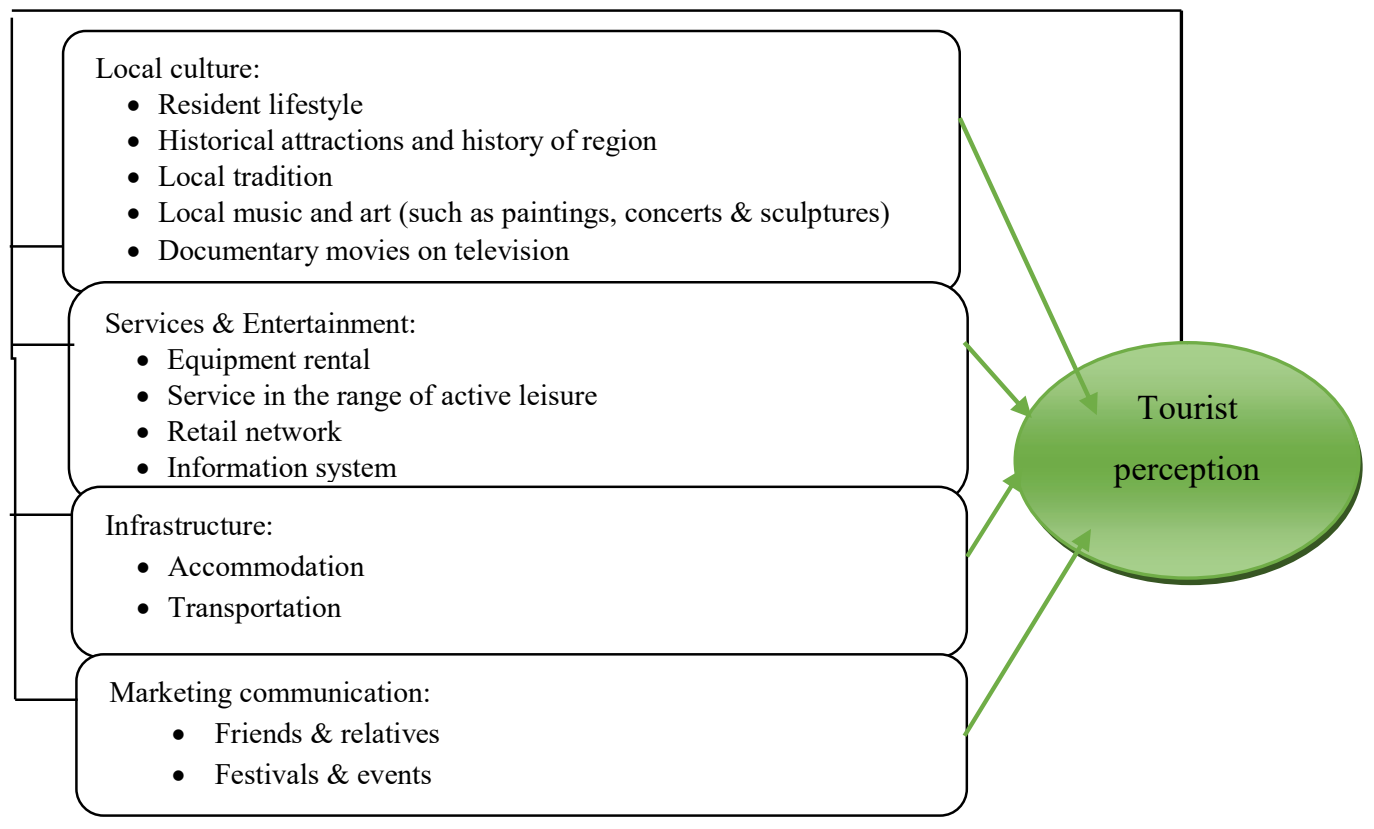

Figure 4. Pull factors influencing tourist perception in the context of rural tourism in Ca Mau province, Viet Nam 
From the findings of data analyzing, it presents a firm proof of how importance of pull factors towards tourist perception through infrastructure, services \& entertainment, local culture as well as marketing communication in rural tourism (figure 4). Among these factors, there are both the positive relation and negative relation between each pull factor and tourist perception.

The impact of tourism infrastructure on tourist perception

The correlation between tourism infrastructure and tourist perception was shown by the multiple regression analysis suggesting the positive significance at $1 \%$ level. The research found that in the case of $\mathrm{Ca}$ Mau province, infrastructure factor was measured by accommodation and transportation indicator, which moderately related to tourist perception $(\mathrm{B}$ infrastructure $=(+) 0.349)$.

This thing underlying confirmed the fact that transportation system is given control of connecting tourism destinations as well as providing transport within the tourism destination (Tourism Task Force of Australia, 2003). Moreover, the essential of infrastructure towards rural tourism area was also illustrated accommodation aspect, which represents the uniqueness of destination image [49]. The result of correlation showing that transportation and accommodation in range of infrastructure are not only crucial in mass tourism, but also moderately influential in tourist perception within the concept of rural tourism.

The impact of services \& entertainment on tourist perception

The result analyzing illustrated that there was a negative correlation of the paired services \& entertainment and tourist perception at $1 \%$ level. However, it demonstrated a weakness when mentioning to the strength of correlation between them $($ B Services \& Entertainment $=(-) 0.110)$.

From the key findings of previous researches, services \& entertainment was highlighted by embracing facilities, systems and services. These items were concerned as a basic component of regional tourist product as well as contributing to tourist movement [44]. In the case study of $\mathrm{Ca}$ Mau province, services \& entertainment was classified by EFA process which included:

1. Equipment rental

2. Service in the range of active leisure

3. Retail network

4. Information system
Even though services \& entertainment was clarified as infrastructure in general tourism concept, it was separated as an independent factor regarding rural tourism in the context of $\mathrm{Ca} \mathrm{Mau}$ province. Due to the main purposes and the scope of rural tourism [22], services \& entertainment simply takes a slightly negative impact on tourist perception. In another words, it means that services \& entertainment contribute to rural tourism development as a supporting factor in a weak level, which overconcentration on this factor would lead to a negative tourist perceived rural tourism. However, it is a goodwill from the public and private sector at the tourism destination especially in the rural area.

The impact of local culture on tourist perception

There are variety of researcher discussing about culture as a determinant in tourism industry. In the scope of this study, it was reconfirmed the positive significance of local culture aspect in tourist perception at $1 \%$ level. There was a strong correlation (B Local Culture $=(+) 0.418)$ between local culture and tourist perception in the case of Ca Mau province, Viet Nam.

This finding was in line with [42] who concluded that culture should be seen as a determinant of tourist perceptions, attitudes, impressions and interpretations of visited sites and host communities. In addition, based on the culture review of [29] and revised for suiting to the case of $\mathrm{Ca}$ Mau province, it found that the tourist perception about rural area included these indicators:

1. Understanding the resident lifestyle

2. Visiting historical attractions and understand the history of region

3. Increasing knowledge about different tradition

4. Enjoying the local music and art (paintings, concerts \& sculptures)

5. Learning local culture through documentary movies mostly through television channel

Furthermore, the result underlined the influential of local culture in developing rural tourism. From the comparison of $r$ value (table 6 ) which defined local culture was the highest impact on tourist perception among the independent factors, it demonstrated that local culture was the key concept of establishing an attractive rural area perceiving by tourists. 
The Impact of Marketing on Tourist Perception

It can be already distinguished and set off the new concept of marketing especially in tourism market nowadays. In the theme of countryside, tourist perceived rural tourism by a variety of information sources in order to make a holiday's decision. That was also one of the momentous findings showing a moderate positive correlation between marketing communication and tourist perception at $1 \%$ level (B marketing communication $=(+) 0.304)$.

The impact of marketing on tourist perception was supported by the previous literatures as [35] indicating the fact of comprehension tourist acquiring information. Because rural tourism is considered as a niche market in term of marketing communication, the existence of a link between market orientation and business success contributes to the application of a long-term marketing concept [37]. From the findings of this research, the marketing channels of rural area with Ca Mau province mostly focus on friends \& relatives and festivals \& events, which means that these two marketing channels take an important play in spreading information about $\mathrm{Ca}$ Mau attraction.

Moreover, implementing the concept of marketing in rural tourism is the direction of developing the distinctive image and enhance the brand awareness in a specific area. By providing target market the necessary information, marketing contributes to the achievement of efficient management in tourism industry.

\subsection{Practical implication}

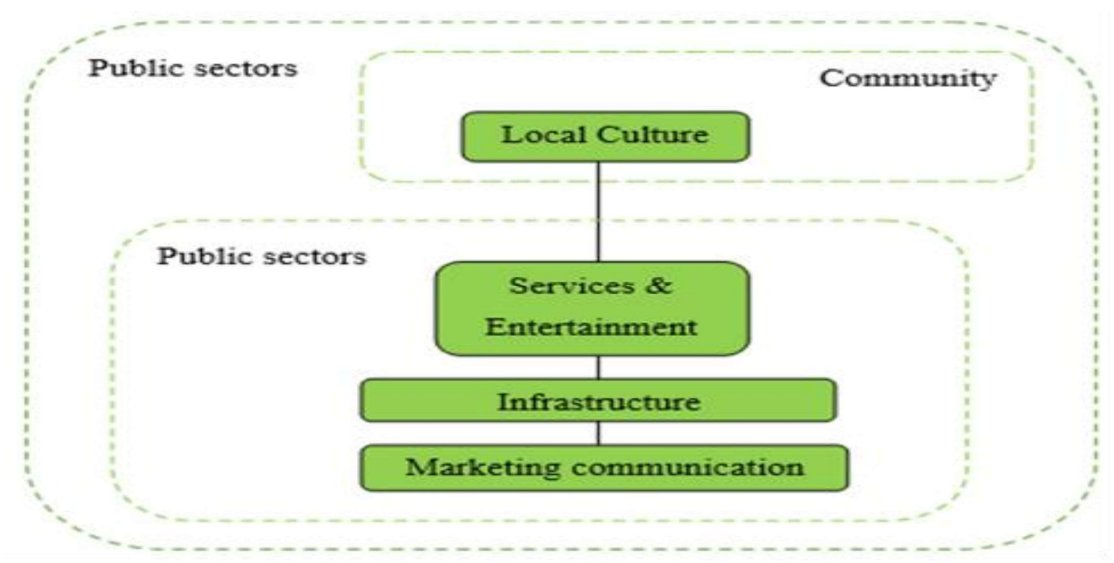

Figure 5. The specific parties take in charge of pull factors in the context of rural tourism in Ca Mau, VietNam

Figure 5 shows that public sectors take general responsibilities for all factors which mean they take on a role of establishing rural tourism management and associating with community groups and private sectors. Meanwhile, the community is in charge of preserving their own culture as well as developing the cultural tourism products by creating tourism groups to supply rural tourism services with the support of public sectors. In addition, private sectors have charge of providing services \& entertainment, infrastructure and managing the process of marketing in line with the organization of the public sectors.

\section{CONCLUSION}

Most of the references about rural tourism development were from the Western countries and did not go through a rigorous scale development procedure in the context of Viet Nam. Therefore, it might be the reason of the differential in classifying the pull factors. Moreover, the questionnaires are written in English and Vietnamese languages, so that it is translated from English into Vietnamese which could include language gaps. Moreover, the respondents of the research were also included international tourists which took an account of $6.8 \%$ respondents answering the questionnaires in English form. Thus, the results findings are limited to be generalized.

In the future, there are suggestions for other who would like to run a research under rural tourism topic as the following: 
Firstly, the research applied exploratory factor analysis and multiple regression analysis to look into the pulls factors influencing tourist perception and examine the relationship between them. The future studies can use confirmatory factor analysis (CFA) and structural equation modeling (SEM) in order to suggest a model representing the link among the latent variables.

Secondly, this study employed the quantitative methodology by using questionnaire to approach the respondent as tourists visiting $\mathrm{Ca} \mathrm{Mau}$ province. The future researches can apply qualitative or mixed method by using both questionnaire and in-depth interview instrument in order to get in touch with the respondents.

Thirdly, the data was collected from the tourist only so that it would be consequently absorbing for studying how the local residents can participate in rural tourism development. Thus, the respondents for the future research can be the community.

Finally, even though the research objectives were not focus on analyzing the market segment of rural tourism, the data was also collected the demographic profile of tourists. Thus, future researches can use the demographic information of tourist to analyze in detail and study of rural tourism market segment.

\section{REFERENCES}

[1]. Anh, T. (2015). Kiểm tra tình hình phát triển du lịch tại Cà Mau. Retrieved from http://ctvcamau.vn/tin-tuc/tintrong-tinh/chinh-tri-xa-hoi/kiem-tra-tinh-hinh-phat-triendu-lich-tai-ca-mau

[2]. Baloglu, S., \& Mangaloglu, M. (2001). Tourism destination images of Turkey, Egypt, Greece and Italy as perceived by US based tour operators and travel agents. Tourism Management, 22, 1-9.

[3]. Beerli, A., \& Martin, J. D. (2004). Factors influencing destination image. Annuals of Tourism Research, 31(3), 657-681.

[4]. Bennett, J. A. (2000). Managing tourism services: A Southern African perspective (2nd ed.). Pretoria: Van Schaik.

[5]. Buhalis, D. (1998). Strategic use of information technologies in the tourism industry. Tourism Management, 9, 409-421.

[6]. Chi, C. G., \& Qu, H. (2008). Examining the structural relationships of destination image, tourist satisfaction and destination loyalty: An integrated approach. Journal of Tourism Management, 29, 624-636.

[7]. Crompton, J. (1979). Motivations for pleasure vacations. Annals of Tourism Research, 6(4), 408-424.

[8]. Diệu, T. (2016). Cà Mau: Sở Văn hóa, Thể thao và Du lịch tổng kết công tác ngành năm 2015 và triển khai phuong huớng, nhiệm vu 2016. Retrieved from $\mathrm{http}: / /$ camautourism.vn/ca-mau-so-van-hoa-the-thao-va- du-lich-tong-ket-cong-tac-nganh-nam-2015-va-trienkhai-phuong-huong-nhiem-vu-2016/

[9]. Duckett, B. (2009). The Longman Dictionary of Contemporary English (5th ed.). Bingley: Emerald Group Publishing Limited.

[10]. Dwyer, L., \& Kim, C. (2003). Destination competitiveness: A model and determinants. Current Issues in Tourism, 6(5), 369-414.

[11]. Farmaki, A. (2012). An exploration of tourist motivation in rural setting: The case of Troodos, Cyprus. Tourism Management Perspectives, 2(3), 72-78.

[12]. Fodness, D. (1994). Measuring tourist motivation. Annals of Tourism Research, 21(3), 555-581.

[13]. Gearing, C. E. (1974). Establishing a measure of touristic attractiveness. Journal of Travel Research, $12(1-8)$.

[14]. Gomezlj, D., \& Mihalic, T. (2008). Destination competitiveness applying different models: The case of Slovenia. Tourism Management, 29(2), 294-307.

[15]. Hennessey, S., Yun, D., MacDonald, R. M., \& MacEachern, M. (2008). A study of cultural tourism: The case of visitors to Prince Edward Island. In The 4th world conference for graduate research in tourism, hospitality and leisure, Antalya, Turkey (pp.580-595). Ankara: Anatolia.

[16]. Ivanovic, M. (2008). Cultural tourism. Cape Town: Juta \& Company.

[17]. Kaul, R. N. (1985). Dynamics of tourism: A trilogy. New Delhi: Transportation and marketing.

[18]. Khuong, M. N., \& Quyen, N. P. (2016). Factors affecting international tourists' perceived service quality and return intention - A study in Ho Chi Minh, Viet Nam. Canadian Center of Science and Education, 8(3), 284-294.

[19]. Kim, Crompton, J., \& Botha, L. (2000). Responding to competition: A strategy for sun/lost city. South Africa Tourism Management, 21(41).

[20]. Kim, S. S., Lee, C., \& Klenosky, D. (2003). The influence of push and pull factors at Korean national parks. Tourism Management, 24(2), 169-180.

[21]. Kipchillat, C. J. (2004). Motivation and perceptions as influencers of consumer choice behavior: The case of tourism to Kenya. Doctoral dissertation, Nova Southeastern University, United States.

[22]. Lane, B. (2010). What is rural tourism? In S. Page \& J. Connell (Eds.), Tourism (p.192): SAGE Publications.

[23]. Lewis, P. G., \& Meadows, A. J. (1995). Canadian tourist information and the UK: Plans and perceptions. Tourism Management, 16(1), 67-72.

[24]. Lim, C. (1997). Review of international tourism demand models. Annals of Tourism Research, 24(4), 835-849.

[25]. MacDonald, R. M., \& Jolliffe, L. (2002). Cultural rural tourism: Evidence from Canada. Annals of Tourism Research, 30(2), 287-513.

[26]. Mazanec, J. (1997). International city tourism: Analysis and strategy. London: Pinter.

[27]. Mazursky, D., \& Jacoby, J. (1986). Exploring the development of store images. Journal of Retailing, 62, 145-165.

[28]. McElroy, J. L. (2003). Small island tourist economies across the lifecycle. In Paper prepared for the International conference, beyond MIRAB: The political economy of small islands in the 21st century, school of economics and finance, Victoria University, Wellington, New Zealand (pp.61-77). Wellington: Asia Pacific Viewpoint.

[29]. Mehmet, K., \& Memis, K. E. (2014). The importance of cultural and gastronomic tourism in local economic 
development: Zile sample. International Journal of Economics and Financial Issues, 4(4), 735-744.

[30]. Middleton, V. T. C. (1994). Marketing in travel and tourism (2nd ed.). Oxford: Butterworth-Heinemann.

[31]. Mihailovic, \& Moris, I. (2012). The role of marketing philosophy in rural tourism development. Tourism and Hospitality Management, 18(2), 267-279.

[32]. Mihailovic, B., \& Moric, I. (2012). The role of marketing philosophy in rural tourism development. Tourism and Hospitality Management, 18(2), 267-279.

[33]. Miller, J. (1997). Cultural tourism worthy of note. Journal of Hotel \& Motel Management, 212(15), 7-17.

[34]. Mohammad, B. A. M. A. H., \& Som, A. P. M. (2010). An analysis of push and pull travel motivations of foreign tourists to Jordan. International Journal of Business and Management, 5(12).

[35]. Molina, A., Gómez, M., \& Consuegra, D. M. (2010). Tourism marketing information and destination image management, African. Journal of Business Management, 4(5), 722-728.

[36]. Morrison, A. M. (2013). Marketing and management tourism destination. London: Routledge.

[37]. Narver, J., \& Slate, S. (1990). The effect of a market orientation on business performance. Journal of Marketing, 5(3), 20-35.

[38]. Naudé, W. A., \& Saayman, A. (2004). The determinants of tourist arrivals in Africa: A panel data regression analysis. In International conference, centre for the study of African economies, St. Catherine's College, University of Oxford (pp.365-391). Munich: MPRA.

[39]. Nedelea, A., \& Okech, R. (2008). Developing rural tourism in South Africa. Bulletin of University of Agricultural Sciences and Veterinary Medicine CLUJ Napoca, Horticulture, 65(2), 256-261.

[40]. Panasiul, A. (2007). Tourism infrastructure as a determinant of regional development. Ekonomika ir vadyba: Aktualijos ir perspektyvos, 1(8), 212-215.

[41]. Poon, A. (1994). Tourism, technology and competitive strategies. Journal of Travel Research, 32(3), 78-79.

[42]. Reisinger, Y., \& Turner, L. W. (2002). Cultural differences between Asian tourist markets and Australian hosts, Part 1. Journal of Travel Research, 40(3), 295-315.
[43]. Richard, G. (1996). Cultural tourism in Europe. Wallingford UK: CBA International.

[44]. Ritchie, J. R. B., \& Crouch, G. I. (2003). The competitive destination: A sustainable tourism perspective. London: $\mathrm{CABI}$ International.

[45]. Schmoll, G. A. (1977). Tourist promotion. London: Tourism International Press.

[46]. Sirakaya, E., \& McLellan, R. W. (1997). Factors affecting vacation destination choices of college students. Anatolla: An International Journal of Tourism \& Hospitality Research, 8(3), 31-44.

[47]. Smith, M. K. (2003). Issues in cultural tourism studies. London: Routledge.

[48]. Tashakkori, A., \& Teddlie, C. (2010). Sage handbook of mixed methods in social \& behavioral research. Thousand Oaks: Sage Publications.

[49]. Truong, T. H., \& King, B. (2009). An evaluation of satisfaction levels among Chinese tourists in Vietnam. International Journal of Tourism Research, 11(6), 521535.

[50]. Um, S., \& Crompton, J. L. (1990). Attitude determinants in tourism destination choice. Annals of Tourism Research, 17(3), 432-448.

[51]. Vietdata (2016). Tổng kết ngành Du lịch Việt Nam năm 2015. Retrieved from http://vietdata.vn/tong-ket-nganhdu-lich-viet-nam-nam-2015-1888570143

[52]. Viet Nam General Statistics Office (2015). Tỷ lẹ họ nghèo phân theo thành thị, nông thôn và phân theo vùng. Retrieved from http://www.gso.gov.vn/default. aspx?tabid $=723$

[53]. Witt, S., \& Witt, C. (1995). Forecasting tourism demand: A review of empirical research. International Journal of Forecasting, 11, 447-475.

[54]. Yamane, T. (1967). Statistics; An introductory analysis. New York: Harper and Row.

[55]. Author: Ngo Thi Ngoc Tram, Management and Tourism Faculty, Burapha University, Chonburi, Thailand, tramngoc461@gmail.com

[56]. Advisor: Sakchai Setarnawat and Ph.d.; Petcharut Viriyasuebphong, Ph.d. Management and Tourism Faculty, Burapha University, Chonburi, Thailand, sakchais@buu.ac.th 


\title{
Những nhân tố kéo tác động đến nhận thức của du khách về du lịch nông thôn: Nghiên cứu trường hợp của tỉnh Cà Mau, Việt Nam
}

\author{
Ngô Thị Ngọc Trâm \\ Đại học Burapha, Thái Lan \\ Email tác giả liên hệ: tramngoc461@gmail.com
}

Ngày nhận bản thảo: 10-9- 2017; Ngày chấp nhận đăng: 02-10-2017; Ngày đăng: 30-6-2018

Tóm tắt-Nghiên cứu định lượng này xác định các yếu tố ảnh hưởng đến nhận thức của du khách trong bối cảnh du lịch nông thôn của tỉnh Cà Mau - tỉnh cực nam của đồng bằng sông Cửu Long. Trong đó, văn hóa địa phương, cơ sở hạ tầng và truyền thông tiếp thị có quan hệ tích cực với nhận thức của du khách, trong khi dịch vụ \& giải trí có mối quan hệ tiêu cực. Nghiên cứu đã thực hiện 400 bảng câu hỏi có cấu trúc để thu thập dữ liệu về các nhân tố này ở Cà Mau và nhận thấy rằng có một ảnh hưởng đáng kể đối với nhận thức của khách du lịch trong ngành du lịch nông thôn, với $58 \%$ sự thay đổi nhận thức về du lịch được giải thích bởi các biến độc lập. Phương trình hồi quy được thiết lập như sau:

\author{
$\mathrm{Y}=1.423+0.343 \mathrm{X} 1-0.082 \mathrm{X} 2+0.273 \mathrm{X} 3+$ \\ $0.189 \times 4$ \\ (Y = Nhận thức của du khách, X1 = Văn hóa địa \\ phương, X2 = Dịch vụ \& Giải trí; \\ $\mathrm{X3}=\mathrm{Co}$ sở hạ tầng; $\mathrm{X} 4$ = Tiếp thị truyền thông) \\ Tù khóa-du lịch nông thôn, những nhân tố tác \\ động, nhận thức du lịch
}

